\title{
Good EFL Learner's Strategy In Enhancing English Mastery: A Case Study at Indonesian College Students
}

\author{
Syawal*, Patahuddin, Nasrullah AS, Ali Wira Rahman \\ English education Department, Muhammadiyah University of Parepare, Indonesia
}

Corresponding Author: Syawal, E-mail: awal.umpar@gmail.com

\section{ARTICLE INFO}

Article history

Received: January 16, 2018

Accepted: March 25, 2018

Published: June 30, 2018

Volume: 9 Issue: 3

Advance access: May 2018

Conflicts of interest: None

Funding: None

\section{Key words:}

Enhancing English Mastery,

Good EFL Learner,

Learner Learning Strategy,

Case Study Approach and Grounded

Theory Method

\begin{abstract}
EFL learner strategy has become a popular issue since English considered as an International language which goes through with international public communication tools. In this study, the researcher focused on verifying learner strategy in enhancing English mastery inside classroom context of Indonesian college student. This study was qualitative research applied case study approach, which involves grounded theory method. The subject of this study was a learner which was considered as good EFL learner. Findings indicated that; a) Good EFL learner acts to obey a rule of learners (discipline). b) Good EFL learner tends to be relaxed and not easily upset (easy going). c) Good EFL learner has an eager to learn or to know something (curiosity). d) Good EFL learner dare to be different or prefers to act differently. In addition, e) Good EFL learner usually determined to follow a particular plan of action and sometimes using words in a clever and funny way (serious and witty).
\end{abstract}

\section{INTRODUCTION}

The study of learner strategy has already been started since 1975 up to now. It was started by (Rubin, 1975) by giving a description of successful language learners. He mentions three characteristics of good learners namely: (1) The good language learner is a willing and accurate guesser, (2) The good language learner has a strong drive to communicate, and (3) The good language learner is often not inhibited (Rubin, 1975). Referring to Rubin findings, the researchers are trying to prove whether these findings also behave to EFL learner in the classroom context especially at Indonesian university.

Based on the national curriculum of Indonesia, English has become a compulsory subject since junior high school up to university levels and even before the enactment of the 2013 curriculum, English classified into additional subjects or local content taught in primary schools from grade 4 to grade 6. Based on these facts, English should no longer a frightening subject for the pupils as well as students of the university. Nevertheless, the fact that only a small number of students who successfully mastered English well (Iftanti, 2012; Patahuddin, Syawal, \& Bin-Tahir, 2017; Taylor \& Henry, 2000), in other words, more than fail. The fact is, of course, a big question mark leads to learning English in
Indonesia either about the teacher, method, strategy or about the pupils or the university students themselves.

In this study, the researchers tried to take part as a nation who wants to contribute to the improvement of the mastery of English as a foreign language. The interest of researchers will be devoted to the learner strategy in learning English inside the classroom. It is based on two things: First, the problem of learning strategy in the classroom has not been much studied in Indonesia compared to the study of learning motivation and learning style. Second, the problem of learner learning strategy in learning English students inside the classroom can give an idea about the characteristics of successful English learner.

The research problems are focused on two important points: (1) how the learner learning strategy in studying English inside the classroom and (2) the consequences brought by learner learning strategy in studying English inside the classroom. By being focused on these issues, this study can give an idea about the learner learning strategy that should be applied by the learners in order to have the good ability in enhancing English mastery, especially learners in Indonesia because most of the theoretical or research results derived from cases that occurred abroad. In addition, the results of this study can be used as a barometer of the results of previous research, especially research in Indonesia. 


\section{LITERATURE REVIEW}

As explained at the beginning that research on learning strategy has been done by Rubin since 1975. In his research (Rubin, 1975) describes four important matters related to the good language learner namely (1) The good language learner is a willing and accurate guesser. (2) The good language learner has a strong drive to communicate. In addition (3) the good language learner is often not inhibited and focused on communication. Moreover, he added that (1) the good language learner is constantly looking for patterns in the language. (2) The good language learner practices. (3) The good language learner monitors his own and speaks to others and (4) the good language learner attends to meaning.

In addition to Rubin, another researcher who studied the learning strategies have also been carried out by (Lan, 2005) in his dissertation about "Language Learning Strategies Profiles of EFL Elementary School Students in Taiwan". (Liang, 2009) who claimed that proper use of language learning strategies leads to the improvement of overall Second Language (L2) or Foreign Language (FL) proficiency as well as specific language skills. Many others researcher which has done research on this problem such as (Chamot \& El-Dinary, 1999); (Alharbi, 2015); (Felder \& Brent, 2005); (Fewell, 2010); (Oxford, 2003); (Samani \& Narafshan, 2016).

Then, refering to indonesian students strategy in enhancing english, there were many researchs findings found by scholars. They are; (Aunurrahman, Kurniawati, \& Ramadhiyanti, 2013) in their research about College students strategies in leraning English language in which 201 college students gave a response and found that the students made use of three major strategies in learning English. Three major strategies applied was cognitive, metacognitive and compensation strategy. Another contribution to this issue was coming from (Diyono, 2009) who investigate learning strategies for EFL students in Developing their vocabulary mastery found that in learning a foreign language, some factors are considered such as language being learned, duration, degree of metacognitive awareness, age, sex, attitudes, personality characteristics, career orientation, language teaching methods and task requirements. In addition, other indonesian researchers who have given their contribution to this major problem such as (Ras, 2013); (Mattarima \& Hamdan, 2011) and (Wahyuni, 2013).

A Recent study in State University of Makassar (Mulyani, Haryanto, \& Dollah, 2014) on their research which concerning at describing the characteristics of good Indonesian EFL learners. Their research report that there are at least seven characteristics of Indonesian good EFL learners: (1) coming from ordinary families and diverse family backgrounds, (2) having high motivation and positive attitude, (3) having extrovert, sociable, confident and goal oriented personality traits and diverse language aptitude, (4) having good intellectual competence (smart), (5) being able to take charge of their own learning by taking various learning actions (creative), (6) being actively participate and not afraid of making mistakes and, (7) having willingness or ability to personalize the language. Moreover, they conclude that good Indonesia
EFL learners should employ various learning strategies in their language learning.

\section{RESEARCH METHODOLOGY}

This study was qualitative research applied case study approach which involves grounded theory method. The grounded theory itself was introduced by (Glaser \& Scott, 1967) and renewed by (Charmaz, 2006; Strauss \& Corbin, 2008). This was conducted at the University of Muhammadiyah Parepare. One of the $7^{\text {th }}$ semester students of English Undergraduate Program participated in this research. The subject of this research was chosen based on some reason; he has the good achievement (average IPK 3,9 since $1^{\text {st }}$ semester), members of FIREDS (English Debating Club), and delegates of Kopertis IX Sulawesi at National University English Debating Championship in Pontianak. This study involves an exploratory study to determine the subject, focused observation, field notes, field notes analysis and converting result analysis into theory. The analysis of field notes adopts the theory of coding by (Charmaz, 2006; Glaser \& Scott, 1967; Strauss \& Corbin, 2008). It consisted of initial coding, focused coding, and theoretical coding.

\section{FINDINGS AND DISCUSSION}

\section{Findings}

\section{Subject backgroud}

The subject of this study was a learner of Muhammadiyah University of Parepare. He is in the $7^{\text {th }}$ semester of English Undergraduate Program. He is categorized Good EFL learners based on some reasons;

a. He has the good academic achievement. His IPK since $1^{\text {st }}$ semester to $6^{\text {th }}$ semester was up to 3,8 .

b. He got some reputable scholarship of achievement such as Scholarship of Kopertis Wil. IX Sulawesi and Local Government Scholarship from Parepare majors.

c. Winning and participating some English Debating national events such as NUDC Kopertis IX Sulawesi, NEED Yogyakarta, HBP competition, PDO, and MAWAPRES.

\section{Learning strategy}

Based on researcher observation toward the subject of this study reports that the subject strategies in attending classroom activities as follows:

\section{A good EFL learner acts to obey a rule of learners (discipline)}

The research subject is a learner who quite disciplined in managing his daily activities. He is always present in class 10-15 minutes before the lecture begins. Based on the observations, the research subject always comes earliest in the classroom. In addition to the discipline of the time, the subject of research has consistently disciplined in doing the tasks given by the lecturers. This is evident from his activi- 
ties when he is in a class. Some college friends often ask him about his tasks is already "finished or not" and the answer is always "yes finished". Similarly, if the lecturers ask to collect tasks, he was always the fastest turn in his assignments. Another subject of discipline in the classroom demonstrates by the subject related to his habits of dress and appearance. Under the rules of the Muhammadiyah University of Parepare, students are not allowed to wear a T-shirt and flip-flops to follow lectures and research subject fact not even breaks the rule. Likewise, with the haircut, he did not even get a warning about it because his haircut is always in accordance with the applicable rules. Therefore, he was highly respected by his peers and loved by the lecturers.

\section{A good EFL learner tends to be relaxed and not easily upset (easy going)}

Easy in this case is not as recognizable, easy going is meant here is the attitude of the research subject that is not overly responsive to the answers or responses that he provided in both discussion and question and answer session with the lecturer. Although the answer or response, especially the structure of the English that he speaks is considered less precise, he continued to speak or ask questions as the given opportunity. He was not afraid of the structure of the English that he uttered. Even if he was reminded of his mistake, he just turned and said "sorry". Likewise, with the tasks of the lecture, despite his reprimand related to the format of the task he was doing, he just nodded and said, "That's my ability".

\section{A good EFL learner has an eager to learn or to know something (curiosity)}

Another strategy that is found in the activity of the subject in the classroom was his curiosity is so high. In the lecturing process, he often asked his lecture of courses given related to the explanations that he considers unclear. Likewise, when a word was spoken by the lecturers that he did not understand or did not clearly heard he always asked his friend beside him. In addition, he also often looks for those words in the dictionary by searching on his cell phone that he was holding. He also frequently requested lecturer or his peer to repeat the explanation that he had not yet understood. The high curiosity of the subject leads him to be diligent in reading a book and discuss with his lecturers and peers. Another thing that can be seen is the habit of preparing a highlighter to mark difficult words or sentences he found in a book and find the answer through the internet or show the book to the lecturers and to his friend. Regarding his habits like these, he often considered being chatty by his friends. Yet, he was not so concerned with the notion of his friends.

\section{A good EFL learner dare to be different or prefers to act differently}

At question and answer session in the classroom, he always stood up when he was given the opportunity to ask questions. Different with his friends, in asking questions, they just sat in their chair. Likewise, in asking the question, the research subject always asks a question in English just the opposite with most of his friend who questioning in Indonesian. In the session of the presentation, the subject of research is quite different. Providing with the "pointer" research subject explained his power point while standing at the corner of the classroom so as not to hinder his friend's view. In his presentation, he did not read the text on the slide, but he explained it pretty well. His friend, in exposing the power point material, although already provided pointers by lecturers, indicates the different thing but they chose to sit in front of a laptop while reading material in their powerpoint slide. In terms of appearance, research subject is also unique, research subject accustomed to wearing a shirt with a vest on the outside. In taking the position of a seat in the class, research subject is always sitting in the front row, dealing with his courses lecturers.

\section{A good EFL learner usually determined to follow a particular plan of action and sometimes using words in a clever and funny way (serious and witty)}

The interesting thing about this research subject is his personality. This subject is very serious in following the lecture, but he is also quite witty. While discussions he often jokes for either closing remarks issued through speech or through facial expression that he shows. It is also often seen when the lecturer of the course provides an explanation, the subject looks quite serious listening to the lecturers, but when the lecturers slipped spontaneously funny sentences, research subject remonstrated funny sentence or the laughter that is unique. The witty of subjects was also recognized by his friends who often become victims of his wit.

\section{Discussion}

Subject's activity in the classroom as found in observation led researchers to draw some substantive conclusions as follows:

The first conclusion, Discipline in learning is one of the attitudes of obedience, which must be owned by learners in order to have a good way of learning. Discipline in learning is seen as factors that affect the learning achievement of learners. Attitudes and behavior do not form on their own discipline and in a short time, but through a long process. Discipline will be realized through early coaching start from the family environment and continue to education in the school. Families and schools are an important place for the development of the discipline in learning of the learners. It could be argued that the discipline of learning is formed not automatically since human beings are born, but are formed due to the influence of the environment. In theory, in order to obtain higher academic achievement, the learner must install a good way of learning and regular. The learning achievement is not necessarily determined by mere intellectual acumen but also learning discipline determine the success of learners achieves the coveted feat. Learners who have the discipline will show the attitude of order and obedience in the study without coercion and pressure from the outside.

The learning achievement is a barometer of the ability of learners after learning activities over a given period. The 
learning achievement is influenced by several factors, one of which is the discipline of learning. Differences discipline of study for each learner raises academic achievement is different also. Some scholars have done research on this matter such as (Bechuke \& Debeila, 2012) which claims that discipline in school which is geared at ensuring the safety of educators and learners and to create an environment conducive to teaching and learning is hampered if the behavior of learners in school disrupts the normal teaching and learning process.

The Discipline of a learner is also very influential on how a teacher/lecturer teaching in the learning process. However, the readiness of a teacher or lecturer in the learning process if there are learners who lack discipline or are not willing to follow the rules that apply to the classroom or school and college will affect to the sustainability of the learning process. This is consistent with research findings stating that how disciplinary problems of learners impacted negatively on the emotional and social well-being of the (Marciniak, 2015; Naicker, 2014)

The second conclusion is that the easygoing attitude is part of a concept that acts as a determinant in the success of the development of the learning process. Easygoing is an important part of every conversation about the human personality. Easygoing is a trait unique to humans, so it can be used to distinguish human beings from other living creatures. Easygoing for someone can be seen through the attitude of her that is the actualization of the person. Humans as organisms that have the drive to develop that ultimately caused it to be aware of where he is. Individual feeling that he does not have the abilities they possess. However, all success depends on how people looked at quality their capabilities. The views and negative attitudes towards the quality of the capabilities of the resulting individual perceive the entire task as something that is difficult to resolve, therefore it is important for a student to always be humble and easygoing so he could mingle with whomever in the classroom.

Third, according to a study conducted by a psychologist, (Kashdan, Sherman, Yarbro, \& Funder, 2013), it is known that people who suffer from social anxiety and have a high curiosity may be more likely to engage in behaviors that avoid conflict. Helping to overcome anxiety is a normal thing when you are anxious or nervous before facing the big day. However, curiosity and excitement about something new, about the new people, might push away your anxieties. Associated with happiness, one theory about happiness is a development of happiness point early on. According to (Kashdan, Dewall, et al., 2013), happiness levels go up and down depending on the positive and negative events experienced. (Kashdan, Dewall, et al., 2013) says, curiosity can increase the happiness of a few degrees. "When we are curious, we are willing to leave the life that is familiar to us and take the risk even if it makes us feel anxious and uncomfortable. Instead of trying desperately to explain and control our world, an explorer who wants to know will embrace uncertainty and see life as something fun to be discovered and learned.

Fourth, the purpose of learning is to humanize humans. The learning process is considered successful if the learner has understood the environment and themselves. Students in the learning process should strive to gradually able to achieve self-actualization as well as possible. Therefore, as a student, the student should dare to try without fear of being wrong. With the courage to try, the course will give valuable experience in the end. This fact is in line with the findings of (Rubin, 1975) which states that the good language learner is often not inhibited.

Fifth, every learner has a learning strategy that is different. There are very serious with no sense of humor, and some are very humorous. Although there are shades of humor, still does not eliminate the nuances of seriousness and discipline. Humorous learners will get a positive value because learners can more enjoy, do not feel scared or depressed. In fact, they became more daring to issue ideas and opinions. With interludes of humor, the atmosphere of learning will be back in the liquid, friendlier and more passionate. Often people say that laughter can make your brain fresh and healthy. Humorous learners can reduce the psychological barriers between learners who can impede learning, such as embarrassment, fear, distress, and others. Physically laugh also will loosen the muscles associated with the important brain cells. Meanwhile, when the learning process can bring a pleasant atmosphere for the learners, classroom full of openness, familiar, then the passion of learning will be higher so that the learners will be easier to remember and understand the subject matter.

\section{CONCLUSION AND SUGGESTION}

As explained in the findings and discussion, the conclusions of this study emphasized on some pretty basic stuff to be owned by EFL learners in the learning process inside the classroom. Its fundamental issue includes: a) good EFL learner acts to obey a rule of learners (discipline), b) good EFL learner tends to be relaxed and not easily upset (easy going), c) good EFL learner has an eager to learn or to know something (curiosity), d) good EFL learner dare to be different or prefers to act differently, and e) good EFL learner usually determined to follow a particular plan of action and sometimes using words in a clever and funny way (serious and witty). Therefore, the researchers believe that through the proposed strategy the EFL learner will be easier in following English course inside the classroom. Moreover, it strongly suggests that EFL learner try to utilize various strategies to make learning activity more effective and pleasant. Lastly, it is suggested for the next researcher to conduct deeper researches about learner learning strategies of good EFL learner with a greater number and various educational background of studies.

\section{ACKNOWLEDGEMENTS}

This work would not have been possible without the financial support of the Lembaga Pengelola Dana Pendidikan (LPDP) Indonresia. I greatly apreciate the support received through International Journals Publication Aid Program serves by LPDP Indonesia. 


\section{REFERENCES}

Alharbi, M. A. (2015). Reading Strategies, Learning Styles and Reading Comprehension: A Correlation Study, 6(6), 1257-1268. https://doi.org/10.17507/j1tr.0606.13

Aunurrahman, Kurniawati, T., \& Ramadhiyanti, Y. (2013). Exploring Indonesian College Students Strategies in Learning English Language. Arab World English Journal, 4(3), 317-330. Retrieved from www.awej.org

Bechuke, a. L., \& Debeila, J. R. (2012). Applying Choice Theory in Fostering Discipline: Managing and Modifying Challenging Learners Behaviours in South African Schools School of Postgraduate Studies. International Journal of Humanities and Social Science, 2(22), 240-255.

Chamot, A. U., \& El-Dinary, P. B. (1999). Children's Learning Strategies in Language Immersion Classrooms. Modern Language Journal, 83(3), 319-338. https://doi org/10.1111/0026-7902.00025

Charmaz, K. (2006). Constructing Grounded Theory (A practical Guide Through Qualitative Analysis). (D. Silverman, M. Bloor, B. Czarniawska, N. Denzin, B. Glassner, J. Gubrium, ... J. Potter, Eds.) (1 ${ }^{\text {st }}$ ed.). SAGE Publications.

Diyono, Y. L. (2009). Learning Strategies for EFL Students in Developing Their Vocabulary Mastery. LITE, 5(1), 1-12. Retrieved from http://dinus.ac.id

Felder, R., \& Brent, R. (2005). Understanding student differences. Journal of Engineering Education, 94(1), 57-72. https://doi.org/10.1002/j.2168-9830.2005.tb00829.x

Fewell, N. (2010). Language learning strategies and English language proficiency: an investigation of Japanese EFL university students. TESOL Journal, 2(June), 159-174.

Glaser, B. G., \& Scott, J. C. (1967). The Discovery of Grounded Theory: Strategies for Qualitative Research. American Sociological Review (Vol. 1). https://doi. org/10.2307/2094063

Iftanti, E. (2012). A Survey of the English Reading Habits of EFL students in Indonesia. TEFLIN Journal, 23, 149-164. Retrieved from http://www.teflin.org/journal/ index.php/teflin/article/view/298/244

Kashdan, T. B., Dewall, C. N., Pond, R. S., Silvia, P. J., Lambert, N. M., Fincham, F. D., ... Keller, P. S. (2013). Curiosity Protects Against Interpersonal Aggression: Cross-Sectional, Daily Process, and Behavioral Evidence. Journal of Personality, 81(1), 87-102. https:// doi.org/10.1111/j.1467-6494.2012.00783.x

Kashdan, T. B., Sherman, R. A., Yarbro, J., \& Funder, D. C. (2013). How Are Curious People Viewed and How Do They Behave in Social Situations? From the Perspectives of Self, Friends, Parents, and Unacquainted Observers. Journal of Personality, 81(2), 142-154. https:// doi.org/10.1111/j.1467-6494.2012.00796.x
Lan, R. L. (2005). Language Learning Strategies Profiles EFL Elementary School Students in Taiwan. University of Maryland.

Liang, T. (2009). Language Learning Strategies - The Theoretical Framework and Some Suggestions for Learner Training Practice. English Language Teaching, 2(4), 199-206.

Marciniak, A. (2015). Effective ways of dealing with discipline problems when teaching adolescent learners, 7, 53-72.

Mattarima, K., \& Hamdan, A. R. (2011). Learners ' Motivation And Learning Strategies In English Foreign Language (EFI) In Indonesian Context, 1(September), $100-108$

Mulyani, S., Haryanto, \& Dollah, S. (2014). GLLs Revisited : Language Learning Strategies Employed by Good Indonesian EFL Learners, 5(37), 146-162. Retrieved from www.iiste.org

Naicker, S. (2014). Teachers' experience of learners with disciplinary problems in secondary school in Kwazulu-Natal, (July).

Oxford, R. L. (2003). Language learning styles and strategies : an overview. Learning Styles \& Strategies, 1-25. https://doi.org/10.1515/iral.2003.012

Patahuddin, P., Syawal, S., \& Bin-Tahir, S. Z. (2017). Investigating Indonesian EFL Learners' Learning and Acquiring English Vocabulary. International Journal of English Linguistics, 7(4), 128.

Ras, F. (2013). Outstanding students' learning strategies in learning English at Riau University, Indonesia. Asian Social Science, 9(12 SPL ISSUE), 20-29. https://doi. org/10.5539/ass.v9n12p20

Rubin, J. (1975). What the "Good Learner" Can Teach Us * Language. TESOL Quarterly, 9(1), 41-51. https://doi. org/10.2307/3586011

Samani, S. K., \& Narafshan, M. H. (2016). Students' Strategic Reactions to the Role of Native Language as a Medium of Instruction in English Classrooms. Journal of Language Teaching and Research, 7(4), 716. https://doi. org/10.17507/jltr.0704.11

Strauss, A., \& Corbin, J. (2008). Basics of Qualitative Research: Techniques and Procedures for Developing Grounded Theory. Sage, $2^{\text {nd }}, 400$.

Taylor, S., \& Henry, M. (2000). a Case Study. Education Policy Analysis Archives.

Wahyuni, S. (2013). L2 Speaking Strategies Employed by Indonesian EFL Tertiary Students Across Proficiency and Gender. University of Canberra. Retrieved from http://www.canberra.edu.au/researchrepository/file/e4225ecd-e3b4-b549-cb92-b44b0c98e414/1/ full_text.pdf 